https://helda.helsinki.fi

\title{
Customers' loyalty to tablet commerce in Nigeria
}

\author{
Olaleye, Sunday
}

2020-02-23

Olaleye , S , Sanusi , I T , Fanning , S \& Salo , J 2020 , ' Customers' loyalty to tablet commerce in Nigeria ' , African Journal of Science, Technology, Innovation and

Development , vol. 12 , no. 2 , pp. 217-229 . https://doi.org/10.1080/20421338.2019.1633096

http://hdl.handle.net/10138/332530

https://doi.org/10.1080/20421338.2019.1633096

acceptedVersion

Downloaded from Helda, University of Helsinki institutional repository.

This is an electronic reprint of the original article.

This reprint may differ from the original in pagination and typographic detail.

Please cite the original version. 


\title{
Tablet Commerce Loyalty in Nigeria
}

\author{
Sunday Adewale Olaleye, ${ }^{1}$ Ismaila Temitayo Sanusi, ${ }^{2}$ Stephen Mark Fanning ${ }^{3}$ and Jari Salo ${ }^{4}$ \\ 1 Department of Marketing, Management and International Business \\ 2 Department of Educational Science \\ 3 School of Business and Law \\ 4 Department of Economics and Management
}

\begin{abstract}
A visit to a traditional or online retailer with the wide variety of electronic devices - desktops, laptops, tablets, and smartphones, clearly, each device is capable of e-commerce activity and a device will be adopted according to a consumer's perceptions of value. Given the importance of human, cultural and personal values, this study purposefully selected Nigerian tablet consumers to better understand the factors that impact on the adoption of mobile commerce and tablet commerce in a developing economy. The survey administered was a hardcopy to the academic community in Nigeria with $(n=312)$ participants. To measure the hypothesized latent constructs through the indicators that represent each of the underlying constructs, the authors embarked on three steps: a confirmatory factor analysis, partial least squares-structural equation modelling and probe the tablet commerce structural relationship by running a bootstrapping. This study filled a vacuum in the extant studies in developing countries by taking into cognizance the prominent status of mobile devices most especially tablet with the theory of trust, privacy, reputation, ease of use and loyalty with gender moderation. The study also gives future direction to the tablet commerce practitioners.
\end{abstract}

Keywords: Tablet Commerce, Ease of Use, Trust, Customer, Loyalty, Gender, Nigeria.

\section{Introduction}

A visit to a traditional or online retailer with the wide variety of electronic devices - desktops, laptops, tablets, and smartphones, clearly, each device is capable of e-commerce activity and a device will be adopted according to a consumer's perceptions of value. According to Widing, Sheth, Pulendran, Mittal, and Newman, (2003) value is a preferred state where a person's human, cultural, or personal values will influence the perceptions of value when selecting a product and evaluation of satisfaction when reflecting on a product.

Given the importance of human, cultural and personal values, this study purposefully selected Nigerian tablet consumers to better understand the factors that impact on the adoption of mobile commerce and tablet commerce in a developing economy. Initially, the situational factors influencing the mobile commerce and tablet market are provided including some of the concerns of Nigerian consumers. Then, the factors that create loyalty (or disloyalty) are presented; ease of use, privacy concerns, reputation, trust, and loyalty. Given the importance of cultural and personal 
values gender influences will also be explored. Following this review of situational factors, seven hypotheses are presented, each hypothesis is then explored and the findings presented.

One point of differentiation in e-commerce is mobility, tablets and smartphones offer greater mobility than desktops and laptops and this provides the opportunity for increased searching and selection (Ghose, Han, and $\mathrm{Xu}, 2013$ ). In the increasingly competitive market of mobile commerce [m-commerce] tablets are often preferred as they offer ease of use advantages over the smaller screen of mobile phones (Ghose, Godfarb, and Han, 2012). A number of scholars have explored the use of tablets; user search behaviour (Ghose, Han, and Xu, 2013; Song, Ma, Wang and Wang, 2013) the influence of age and gender in tablet adoption (Hur, Kim and Kim, 2014), the impact of tablets on productivity and satisfaction by business users (Khuhro, Qureshi, Humayon, Tahir and Khan, 2016, Bredican, 2016, Chan-Olmsted and Shay, 2016, Kim, Lim, Proctor, and Salvendy, 2016), a cross cultural analysis of t-commerce (Olaleye, Salo and Ukpabi, 2018). Nevertheless, the loyalty of tablet users when undertaking t-commerce has received scant attention, moreover the loyalty of tablet users in a developing economy remains inchoate. Therefore, this study intends to focus on the emergence of $\mathrm{t}$-commerce in developing nation of Nigeria.

The wide-spread adoption of modern technology tools, such as tablets, by both business and consumers has created an environment of improved collaboration, networking and co-creation, and mutual understanding, and this has fostered sales growth (Romero and Molina 2011, Curry and Cherner 2016, Olaleye, 2016, Olaleye, Oyelere, Sanusi and Joseph, 2018). Xu, Chan, Ghose, and Han (2016) provide an example, they tell the success story of tablet adoption of the Taobao shopping platform, a subsidiary of Alibaba Group. The four-year observation on Taobao, reveals that consumer's spending increased by $6.7 \%$ as the tablet browsing increased actively by $5.5 \%$ after the tablet adoption. They stated that tablet adoption had a considerable impact on Taobao annual sales revenue of US\$923.5 million. Despite these outstanding records in Taobao, some online retailers have not given appropriate attention to the nuances of tablet commerce behavior and to make their sites more tablet friendly. This is an important consideration as tablet adoption is in the early adopter stage of the product life cycle (Mulpuru and Epps 2011).

Today, most website software packages, for example the industry leader WordPress have recognized the importance of mobile commerce and enabled their products to be mobile responsive for mobile web browsing. Being mobile responsive improves navigation, ease of use and the shopping experience, (Xu, et al., 2016), the shopping experience is then augmented by the tablet's 
larger screen (Ghose, et al., 2013), larger keyboard, and increased battery life. The appeal of tablets to include the features of smartphones has created a new product category the 'phablet' which provides the users with the ability to employ their tablet as a mobile telephone. Choice between a smartphone and a tablet is also influenced by brand preferences, product preference, and user lifestyle, location, and perceived convenience (Xu, et al. 2016). Whilst some scholars have examined gender and online behaviour, socio demographic differences in ICT use, and ecommerce and mobile commerce adoption (Weiser 2000, Rodgers, and Harris 2003, Olatokun, 2009, Faqih, and Jaradat 2015) examination of gender differences and tablet use are limited.

Despite the enormous potentials of tablet commerce globally, Nigeria still takes exception in the aspect of online shopping security and privacy. Most Nigerians have experienced either an online attack or an attempted attack, therefore, Nigerians, have a heighted awareness of the online risks and this has created a negative attitude and decreased the interest for online shopping. This development led to attitudes of risk and benefit recognition associated with online shopping. Building the trust of Nigerian online consumers will take time and effort, however, trust is generally regarded as a component of customer loyalty and an indicator of future consumption behaviour (Strauss and Seidel, 2004; Buttle and Maklan 2015). There are many electronic and mobile commerce websites in Nigeria and for adoption to increase there needs to be consumer confidence through the behaviour of reputable online retailers. While customers perceive risks they also see benefits - buying online is convenient and saves money, time, and effort and often as co-creators (Vargo and Lusch, 2004) can influence the product delivery experience and bridges the gap or distance between the seller and the buyer. Nevertheless, a feeling of insecurity is competing with their desire to become online buyers. The study argues that female perception of ease of use, reputation, trust and privacy concerns on a tablet for online shopping is different from male loyalty to tablet commerce.

There are many existing studies on e-commerce and mobile commerce, for example (Bekele, 2000; Chen and Ning, 2002; Garcia-Mnrillo, 2004; Kamel and Hussein, 2004; Molla and Licker, 2005; Nilashi, Ibrahim, Mirabi, Ebrahimi and Zare, 2015; Yoon and Occena, 2015; Piao, Li, Pan and Zhang, 2016; Thakur, 2016) but mobile commerce research on reputation, trust, loyalty, ease of use, and perceptions of privacy concerns in an emerging market has received little scholarly attention. This research project was designed to close this research gap, as such, this study intends 
to examine the consumer behaviour of tablet users in the emergent market of Nigeria; in particular this study will explore the considerations of ease of use, privacy concerns, reputation, trust, loyalty and perceptions of risk and how this is influenced by gender to form a conceptual framework for tablet commerce in an emerging market.

This study intends to answer the following research questions:

RQ1: What are the factors responsible for loyalty to tablet commerce in Nigeria?

RQ2: Are there gender differences between male and female tablet users in Nigeria and to what extent?

RQ3: Are there differences between male and female in how they perceive privacy, trust, reputation, ease of use and loyalty to tablet commerce in Nigeria?

The following hypotheses are tested in the study:

H1: The relationship between ease of use and loyalty is higher among female than male.

$\mathrm{H} 2$ : The relationship between ease of use and reputation is higher among male than female.

H3: The relationship between tablet user privacy and reputation is higher among male than female.

H4: The relationship between privacy and trust of tablet user is higher among female than male.

H5: The relationship between tablet commerce, vendor reputation and loyalty is higher among male than female.

H6: The relationship between tablet commerce, vendor reputation and trust is higher among male than female.

H7: The relationship between tablet user trust and loyalty is higher among female than male.

Part one of the study introduces tablet commerce while the part two synthesizes the relevant extant literature on electronic and mobile commerce as a precedent of tablet commerce and develop hypotheses for the study based on the literature reviewed. The third part dwells on the methodology for the study. Fourth part focuses on data analysis and the findings of the result. The last part of this study captures the theoretical contribution, managerial implication and the future direction for the study. At this point, this research contributes to the tablet commerce literature by developing a conceptual framework, linking the relationships between tablet commerce vendor's website reputation, trust, privacy, ease of use as an antecedent of loyalty to tablet commerce. 


\section{Literature and Hypotheses Development}

\subsection{Consumer Engagement with Tablet}

Mobile devices have given customers the ability to shop when and where they wish and the power to look for the best deal possible whether online or in a brick-and-mortar shop. So, more and more customers now expect a seamless shopping experience between sites and stores. The growing use of mobile technology such as tablet device, as a vehicle for shopping, is an overriding experience in e-commerce. One of the driving forces of this trend is the increasing number of mobile device users. For example, in reports by the Pew Research Center $(2013$, 2018), a third of American adults owned a tablet in 2013, including a majority of those in higher income households and the number increased to 51 percent by January 2014 and it is estimated to reach 53 percent by November 2018. The proliferation of tablets is raising the expectations of these affluent digital consumers regarding shopping online. The quality and size of the tablet screen create an ideal interface for seeking and reading digital information unlike the mobile phone (Church et al., 2007; Sohn et al., 2008). According to Mulpuru and Epps (2011), a significant percentage of consumers who currently own tablets report shopping on their tablets as many of these shoppers prefer to browse web stores and purchase on their tablets instead of using their PCs or smartphones.

Online sellers have been facing increasingly fierce competition in persuading potential consumers with the rapid development of e-commerce (Wang, Cui, Huang and Dai, 2016). This situation is because of the difficulty that online seller encountered to provide kinds of special service to consumers like the traditional offline markets where they can touch and try out the product before purchase (Haubl and Trifts, 2000). The same products can be perceived as largely different and different product perceived as the same due to its presentation or sold by sellers with recognizable reputation levels in an online community. Research has supported the positive and significant relationship between perceived ease of use and consumer trust (Gefen, Karahanna, and Straub 2003; Tung, Chang, and Chou 2008) and reputation has frequently been suggested as an important factor that contributes to customer trust (Agag and El-Masry, 2016). In an m-commerce context, customers who cannot trust an m-vendor will not be loyal to that m-vendor, even when they are satisfied with the products/services provided. Establishing procedures to enhance user's trust may lessen customers' privacy concern since privacy and trust are directly related (Shah, Okeke and 
Ahmes, 2013) as (Chang et al., 2005) noted that many online firms have successfully implemented various procedures to comply with good data and information practices.

\subsection{Ease of Use}

Perceived ease of use (EOU) has been defined as "the degree to which a person believes that using a particular system would be free of effort" (Davis 1989, 320). EOU is associated with the "userfriendliness" of a website (Ramayah and Ignatius, 2005) which according to them, if the hassle proves to outweigh the benefit of purchasing through the net, then potential Internet shoppers would prefer to purchase through conventional channels. This indecisiveness depicts that EOU leads to Internet shopper's willingness or unwillingness to engage in Internet shopping. Liu, Chen, and Zhou (2010) see EOU as how easy the online purchasing is for customers to conduct an external search in cyberspace and internal navigation and search within the website. The less complexity in operating a system, positive attitude could be developed subsequently towards intention and behavior (Davis, 1989; Venkatesh and Davis, 2000). Also, with the less effort that is required to operate a system, the more it can lead to increase in job performance by regular use of the system. Several studies have proposed that a system that is easy to use will be more widely accepted than the one that is not as easy to use (Jantan et al., 2001; Ndubisi et al., 2001; Ramayah et al., 2002; Ramayah et al., 2003, Selim, 2003; Ramayah et al., 2005; Ramayah and Lee, 2005; Ramayah, 2005, 2006, 2010; Ramayah and Ignatius, 2005; Ramayah and Lo, 2007). Based on previous evidence that ease of use of e-commerce platform will lead to its wide acceptance and that positive attitude could be developed towards intention and behaviour, then easiness of transacting through tablet commerce may affect the reputation of the online merchant website and as well influence purchase of products or service from the e-vendors in the future. Thus, the following hypotheses are developed:

H1: The relationship between ease of use and loyalty is higher among female than male. H2: The relationship between ease of use and reputation is higher among male than female.

\subsection{Privacy}

Westin (1967) defined privacy as the desire of people to choose freely under what circumstances and to what extent they will expose themselves, their attitude, and their behavior to others. Completing a transaction without disclosing some personal data is very difficult, even if that disclosure is made to a trusted third party, then, privacy becomes a concern in e-commerce 
(Ackerman, Cranor, and Reagle, 1999). Online privacy concern leads to a lack of willingness to provide personal information online, rejection of e-commerce, or even unwillingness to use the Internet. Consumer concerns over privacy not only limit the development of electronic commerce but may also affect the validity and completeness of consumer databases, which may lead to inaccurate targeting, wasted effort, and frustrated customers. To avoid such inaccuracies, Internet companies should assure users that their privacy is well protected (Wua, Huang, Yen, and Popova, 2012). A survey by Hinde, (1998) found that $65 \%$ of respondents were more willing to provide information online if they had a guarantee that this information would not be misused. Many researchers propose that concerns for information privacy are a huge barrier for e-commerce businesses and according to (Odom, Kumar, and Saunders, 2002), businesses anticipate that more than a trillion dollars of e-commerce could be conducted if customers' concerns for privacy could be adequately addressed. Gilbert, (2001) further opined that consumers would cooperate better if they had the right to force companies to delete personal information later. Earlier studies have found privacy to be a key antecedent to trust e-commerce (Ackerman, Cranor, and Reagle, 1999; Metzger, 2004). As tablet commerce is not exempted from privacy concerns, this study will further validate previous assertions and probe further if privacy concerns will affect reputation and trust in tablet commerce. Thus, the following hypotheses are proposed:

H3: The relationship between tablet user privacy and reputation is higher among male than female.

H4: The relationship between privacy and trust of tablet user is higher among female than male.

\subsection{Reputation}

Reputation has been defined as a collective measure of trustworthiness according to members' ratings in a community (Josang, Ismail, and Boyd 2007) and as a measure of a company's credibility, which results from the relationship among the company's promises and fulfilments (Casalo, Flavian, and Guinaliu 2007). In the electronic commerce context, reputation can be defined in two folds as evident above. Consumers who do not have an experience with an online service provider rely on the reputation of the online provider to assess the trustworthiness of their service provider (Chen 2006; Koufaris and Hampton-Sosa 2004). Empirical evidence of the relationship between reputation and consumer trust has been provided by previous studies (Kim, $\mathrm{Xu}$, and Koh 2004; Teo and Liu 2007; Hsu et al. 2014; Han, Nguyenb, and Lee 2015) which revealed that the positive reputation of online service providers significantly influenced consumers' trust in online vendors (Chen 2006; Teo and Liu 2007; Gregori, Daniele, and Altinay 
2014). Vermeulen and Seegers (2009) revealed that consumers' feedback influences the reputation of the hotel and the attitudes toward it. Also pointed out by Toms and Taves (2004) that a positive online company reputation can be formed through the assessment of a third party like the rating services on the website and indirectly through linking of the website. Some studies have pointed out that a positive company reputation results in a trusting relationship between the consumers and the company, while the existence of a negative company reputation results in a less trusting relationship (Smeltzer 1997; Beldad, de Jong, and Steehouder 2010; Herbig, Milewicz, and Golden 1994) and that when the company fails to fulfil the consumers' intentions, it results in the destruction of its reputation. Also, investing in corporate reputation is a means to augment loyalty, thereby stabilizing corporate relationships to consumers (Selnes, 1993; Helm, 2006). Since empirical evidence exist of the relationship between reputation and consumer trust in e-commerce and reputation and loyalty, this study will validate this and as well ascertain the relationship that exists between reputation, trust and consumers loyalty in tablet commerce. Thus, the following hypotheses are developed:

H5: The relationship between tablet commerce vendor reputation and loyalty is higher among male than female.

H6: The relationship between tablet commerce vendor reputation and trust is higher among male than female.

\subsection{Trust}

Trust is a belief that trusted parties would behave by the trusting party's certain expectations by exhibiting ability, integrity, and benevolence (Luhmann 1979; Mayer et al. 1995). According to Luhmann (1979), trust promotes transaction success because it can reduce social uncertainties that would otherwise be too complex, if not impossible, to figure out on a rational basis. Trust in online environment has been found to be significant in decision making for online transactions (Gefen, 2000; Pavlou,2003; Gefen et al.,2003; Corbit et al., 2003; Ba and Pavlou, 2006; Sha, 2009) and has been found to be a key predictor of both initial online purchase and repeat purchase (Flavian et al. 2006; Gefen 2002; Li et al. 2006; Lim et al. 2006; Qureshi et al. 2009). Corritore, Kracher, and Wiedenbeck, (2003) opined that customers must depend more heavily on trust in the online vendor to gain the necessary assurance. Slow development of e-commerce was attributed to consumers' lack of trust in purchasing on the internet in North America (Kim and Byramjee, 2014) and India (Kuo, 2013).Trust among the many influencing factors has been found to be a key predictor for customer retention for example, Flavian et al. (2006); Gefen (2002); Qureshi et al. 
(2009) agreed with this view and that due to trust crucial ability to promote risk-taking behavior in the case of uncertainty, interdependence, and fear of opportunism, the seller can have a repeat sales from the buyer (Mayer et al. 1995; McKnight et al. 1998). Consumers thus rely on their trust in the vendor or the Internet to mitigate the effects of their uncertainty toward their relationships (as buyer and seller) in the online environment (Ha and Stoel, 2008). Currently, tablet commerce as an emerging subset of m-commerce confronts the issue of trust (Chong, 2013). It is hypothesized that:

H7: The relationship between tablet user trust and loyalty is higher among female than male.

\subsection{Loyalty}

Loyalty in online settings has been defined "as the customer's favorable attitude toward an electronic business resulting in repeat buying behavior" (Anderson and Srinivasan, 2003, 125). According to Smith (1998), loyalty occurs when "customer feels so strongly that you can best meet his or her relevant needs that your competition is virtually excluded from the consideration set and the customer buys almost exclusively from you". Previous studies (Keller,1993; Anderson and Srinivasan, 2003; 125) defined e-loyalty “as the customer's favorable attitude toward an electronic business resulting in repeat buying behavior". Loyalty is a term often used by retailers, including eretailers and e-vendors. While retaining existing customers and converting them into loyal customers are challenging issues for retailers, Gruen, Summers, and Acito, (2000) have agreed that continuous loyalty with a service provider is explained by a positive consumer attitude. Loyalty has been widely studied in online marketing literature and later in social media (Hawkins and Vel, 2013). In the same vein, attitude, which includes the affective responses and feelings toward the behaviour or object, has been previously investigated as one of the most important antecedents of loyalty intention (Ajzen, 1991; Robinson and Smith, 2002). This study defines loyalty as the degree to which consumers want to purchase products or service from tablet commerce vendors in the future. Figure 1 presents the conceptual framework and hypotheses. 


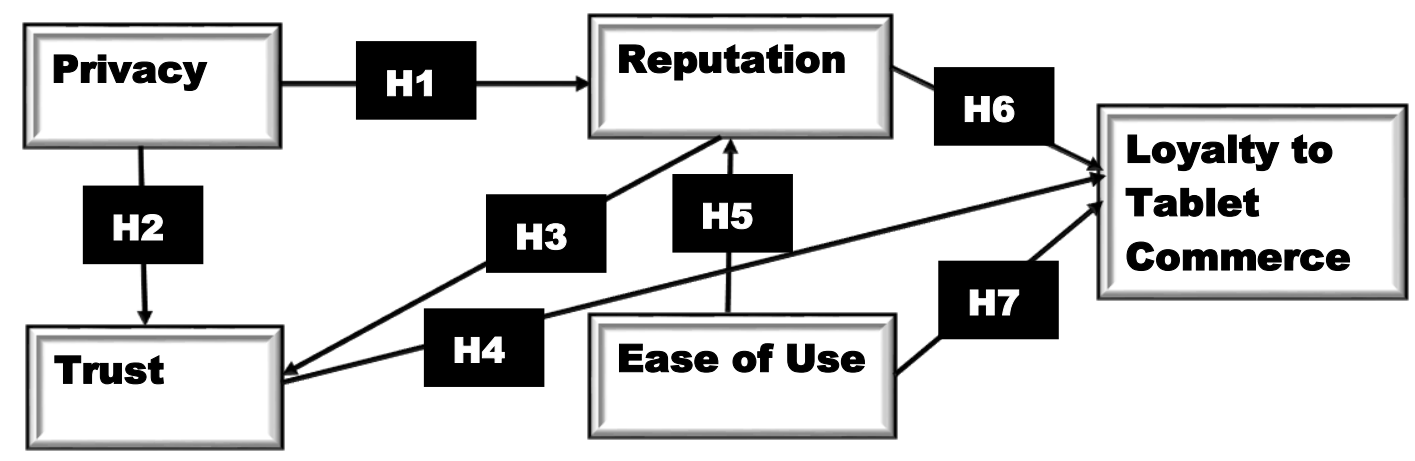

Fig. 1. Conceptual framework and hypotheses

\section{Research Methodology and Sample}

\subsection{Tablet Commerce Context}

The study employed random sampling and used Sango Otta, Ogun State, Nigeria as the setting for the study, based on 526,565 population size, $85 \%$ confidence level, and $4 \%$ margin of error. Sango Otta was chosen for this study because it is an industries hub city in the Western part and the third largest convergence of industries in Nigeria. The participants of the study consist the age bracket 25 and 65 . The sample consist tablet commerce consumers that like trendy technologies and have the propensity to cleave to the online market. The sample represents the population of tablet commerce in Nigeria South-West geopolitical zone.

\subsection{Questionnaire Development}

The authors designed questionnaire for this study based on the measurement of the ease of use Davis (1989), trust and loyalty Lin and Wang (2006), privacy and reputation Li (2014). The study employs 7-Point Likert Scales ranging from strongly disagree (1) to strongly agree (7). The authors explore tablet commerce consumer's demographics, shopping experience and questions on shopping easiness, vendor website reputation, trust, privacy, loyalty and social media use.

Table 1: Source of observed variables used to measure latent constructs

\footnotetext{
Constructs and measurement items

Reputation (Li 2014)

This t-commerce vendor is well known

This t-commerce vendor has a good reputation
} 
This t-commerce vendor has a reputation for being honest

This t-commerce vendor has a reputation for caring about its customers

This t-commerce vendor has a reputation for being able to meet its obligations towards the customers

This t-commerce vendor has a reputation for being consistent

This t-commerce vendor has a reputation for fulfilling its promises

Privacy (Li 2014)

I am confident that I know all the parties who collect the information I provide during the use of this tcommerce website

I am aware of the exact nature of information that will be collected during the use of this t-commerce website I am not concerned that the information I submitted on this t-commerce website could be misused

I believe there is an effective mechanism to address any violation of the information I provide to this $\mathrm{t}$ commerce website

Trust (Lin and Wang 2006)

This t-commerce vendor is trustworthy

This t-commerce vendor keeps promises and commitments

This t-commerce vendor keeps my best interests in mind

This t-commerce vendor meets my expectations

Ease of Use (Davis 1989)

This t-commerce website is easy to use

It is easy to become skillful at using this t-commerce website

Learning to operate this t-commerce website is easy

This t-commerce website is flexible to interact with

My interaction with this t-commerce website is clear and understandable

Loyalty (Lin and Wang 2006)

My preference for this t-commerce website would not willingly change

It would be difficult to change my beliefs about this t-commerce website

Even if close friends recommended another t-commerce website,

my preference for this t-commerce website would not change

I will buy from this t-commerce website the next time I purchase the above-mentioned product/service

*Note: Items of the constructs adopted from the corresponding authors

Table 2: Overall CFA for the measurement model.

\begin{tabular}{|c|c|c|c|c|c|c|}
\hline $\begin{array}{l}\text { Constructs and } \\
\text { measurement items }\end{array}$ & $\begin{array}{l}\text { Standardized } \\
\text { loadings }\end{array}$ & Mean & SD & CA & CR & AVE \\
\hline Loyalty & & & & & .864 & .615 \\
\hline LO1 & 0.79 & 4.50 & 1.78 & 943 & & \\
\hline LO2 & 0.82 & 4.54 & 1.70 & .943 & & \\
\hline LO3 & 0.71 & 4.13 & 1.70 & 945 & & \\
\hline LO4 & 0.80 & 4.92 & 1.63 & 942 & & \\
\hline Reputation & & & & & .934 & .671 \\
\hline RE1 & 0.69 & 5.32 & 1.56 & 942 & & \\
\hline RE2 & 0.81 & 5.34 & 1.47 & .942 & & \\
\hline RE3 & 0.86 & 5.17 & 1.49 & 941 & & \\
\hline RE4 & 0.84 & 5.04 & 1.48 & .942 & & \\
\hline RE5 & 0.86 & 5.21 & 1.40 & 941 & & \\
\hline RE6 & 0.84 & 5.21 & 1.40 & 941 & & \\
\hline RE7 & 0.81 & 5.29 & 1.40 & 941 & & \\
\hline Trust & & & & & .911 & .719 \\
\hline TR1 & 0.85 & 5.44 & 1.60 & 944 & & \\
\hline TR2 & 0.87 & 5.11 & 1.67 & 943 & & \\
\hline TR3 & 0.85 & 5.03 & 1.54 & .941 & & \\
\hline TR4 & 0.82 & 4.84 & 1.44 & 941 & & \\
\hline Ease of Use & & & & & .908 & .664 \\
\hline EA1 & 0.79 & 5.42 & 1.58 & 941 & & \\
\hline EA2 & 0.77 & 5.22 & 1.58 & .942 & & \\
\hline EA3 & 0.86 & 5.38 & 1.52 & 944 & & \\
\hline EA4 & 0.80 & 5.19 & 1.54 & 942 & & \\
\hline EA5 & 0.85 & 5.16 & 1.40 & .947 & & \\
\hline
\end{tabular}




\begin{tabular}{|c|c|c|c|c|c|c|}
\hline Privacy & & & & & .821 & .540 \\
\hline PR1 & 0.78 & 4.09 & 1.70 & .941 & & \\
\hline PR2 & 0.82 & 4.84 & 1.51 & .941 & & \\
\hline PR3 & 0.56 & 4.08 & 1.69 & .941 & & \\
\hline PR4 & 0.74 & 4.79 & 1.48 & .941 & & \\
\hline
\end{tabular}

\subsection{Sample}

The survey administered hardcopy questionnaire due to the low online culture in Nigeria, high exorbitant of internet data and phobia of online insecurity. The questionnaire was designed in the English language since the English language is a lingua franca in Nigeria and virtually all the community members speak and write the English language. The participants in the survey $(n=312)$ including 182 (58\%) male, 130 (42\%) female, 248 (64.8\%) bachelor's degree students, 197 (63\%) High school diploma students, 84 (27\%) master's degree students 15 (5\%), 1(0.2\%) PhD holders $10(3 \%)$ and $6(2 \%)$ with no formal education. A greater percentage of our sample are highly educated. Many of them have engaged in online shopping with tablet and with their online shopping experience bought goods like clothing, accessories, electronics goods, sports equipment, books, apps and games, kitchen utensils, computers and mobile phones. The common social media platform used on a tablet in this study made up of Facebook, Twitter, YouTube, Google, Instagram, LinkedIn, Snapchat, Pinterest, Flickr, Picassa, Shopkick, Viadeo, Delicious, Foursquare and the primary use of tablet indicated are surfing the internet, GPS and for social media.

Table 3: Demography Characteristics of the Respondents

\begin{tabular}{|c|c|c|c|}
\hline Variable & Classification & Frequency & Percentage\% \\
\hline Age & $\begin{array}{l}<25 \\
25-34 \\
35-44 \\
45-54 \\
55-64 \\
65\end{array}$ & $\begin{array}{l}- \\
261 \\
36 \\
12 \\
2 \\
1\end{array}$ & $\begin{array}{l}- \\
84 \% \\
12 \% \\
4 \% \\
1 \% \\
0 \%\end{array}$ \\
\hline Gender & $\begin{array}{l}\text { Male } \\
\text { Female }\end{array}$ & $\begin{array}{l}182 \\
130\end{array}$ & $\begin{array}{l}58 \\
42\end{array}$ \\
\hline Education & $\begin{array}{l}\text { High School/Diploma } \\
\text { Bachelor's Degree } \\
\text { Master's Degree } \\
\text { PhD } \\
\text { No Formal Education }\end{array}$ & $\begin{array}{l}84 \\
197 \\
15 \\
10 \\
6\end{array}$ & $\begin{array}{l}27 \\
63 \\
5 \\
3 \\
2\end{array}$ \\
\hline $\begin{array}{l}\text { Frequency of tablet for } \\
\text { shopping }\end{array}$ & $\begin{array}{l}<1 \text { time } \\
1-5 \text { times } \\
11-20 \text { times } \\
21-30 \text { times } \\
>30 \text { times }\end{array}$ & $\begin{array}{l}110 \\
6 \\
14 \\
151 \\
31\end{array}$ & $\begin{array}{l}35 \\
2 \\
4 \\
48 \\
10\end{array}$ \\
\hline
\end{tabular}




\begin{tabular}{|c|c|c|c|}
\hline Users of Social Media on & Yes & 297 & 95 \\
\hline Tablet & No & 15 & 5 \\
\hline \multirow[t]{7}{*}{ Income } & Less than $¥ 140,000$ & 233 & 75 \\
\hline & 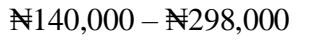 & 22 & 7 \\
\hline & $\aleph 340,000-\approx 497,000$ & 10 & 3 \\
\hline & $\approx 230,000-N 398,000$ & 7 & 2 \\
\hline & $¥ 450,000-\approx 597,000$ & 10 & 3 \\
\hline & 丹598,000 - $¥ 697,000$ & 30 & 10 \\
\hline & $\mathrm{N} 7000,000$ or more & - & - \\
\hline \multirow[t]{3}{*}{ GPS on Tablet } & Yes & 126 & 40 \\
\hline & No & 183 & 59 \\
\hline & Not Sure & 3 & 1 \\
\hline \multirow[t]{5}{*}{ Education } & Diploma/Technical & 83 & 27 \\
\hline & Bachelor's Degree & 198 & 63 \\
\hline & Master's Degree & 15 & 5 \\
\hline & $\mathrm{PhD}$ & 10 & 3 \\
\hline & No formal qualification & 6 & 2 \\
\hline
\end{tabular}

360 Nigerian Naira (\#) is equivalent of 1 dollar (\$)

\section{Results}

To measure the hypothesized latent constructs through the indicators that represent each of the underlying constructs, the study embarked on three steps. The authors conducted a confirmatory factor analysis (CFA) to delineate the constructs theoretically. In the second part, the authors test the partial least squares structural equation modeling (PLS-SEM) and probe the mobile commerce structural relationship for Average Variance Extracted (AVE), Composite Reliability (CR), and R Square. In the third part, the authors run a bootstrapping with 5000 samples and 312 cases $(N-1)$ to check the Path Coefficients Mean, Standard Deviation and T-Values to ascertain their conformity to the set criteria of 1.96 and their significant levels.

\subsection{Measurement Model}

There is a belief among the researchers that PLS-SEM with its predictive potentiality and CBSEM with the incremental fit index and badness of fit index as a set criterion for CFI, TLI, and SRMR should be independent (Sarstedt, Ringle, Henseler, and Hair 2014). Nevertheless, (Ringle, Sarstedt, and Straub. 2012, Wong 2013, Sarstedt et al. 2014) noticed the increase in the application of SmartPLS software in the different research domain. The authors are motivated to use SmartPLS software because it is easy to use and useful for behavioural research to examine the strength of association (Lowry, and Gaskin 2014). The authors used SPSS 22.0 for Cronbach's alpha $(\alpha)$ reliability test and SmartPLS 2.0 to draw out factor loadings, composite reliability (CR) and average variance extracted (AVE) based on reflective measurement which was recommended for attitudinal study (Coltman, Devinney, Midgley, and Venaik 2008, Akbar, Pilcher, and Perrin 
2012). PLS was further used to run multigroup analysis and moderation effect based on male and female as evident in Figure 3. Table 3 shows the turnout of the data analysis. The factor loadings fall within the range of 0.71 to 0.87 and above the brink of 0.5 . Composite reliability for the study exceeds the thresholds of 0.7 with the minimum of 0.83 and maximum of 0.93 for the five latent variables while variance extracted also conform to the rule of thumb of 0.5 with the minimum output of 0.60 and maximum of 0.72 (Bagozzi and Yi 1988). The Cronbach's alpha ( $\alpha$ ) for the items above the limit of 0.7. Cronbach's alpha is an indicant of reliability, and it explains the relationship of the items with the latent variable (Tavakol and Dennick, 2011).

In Table 2 the root of the factor correlation is compared with AVE values to establish discriminant validity. The tablet commerce study in the context of Nigeria was found discriminant valid (Fornell and Larcker 1981).

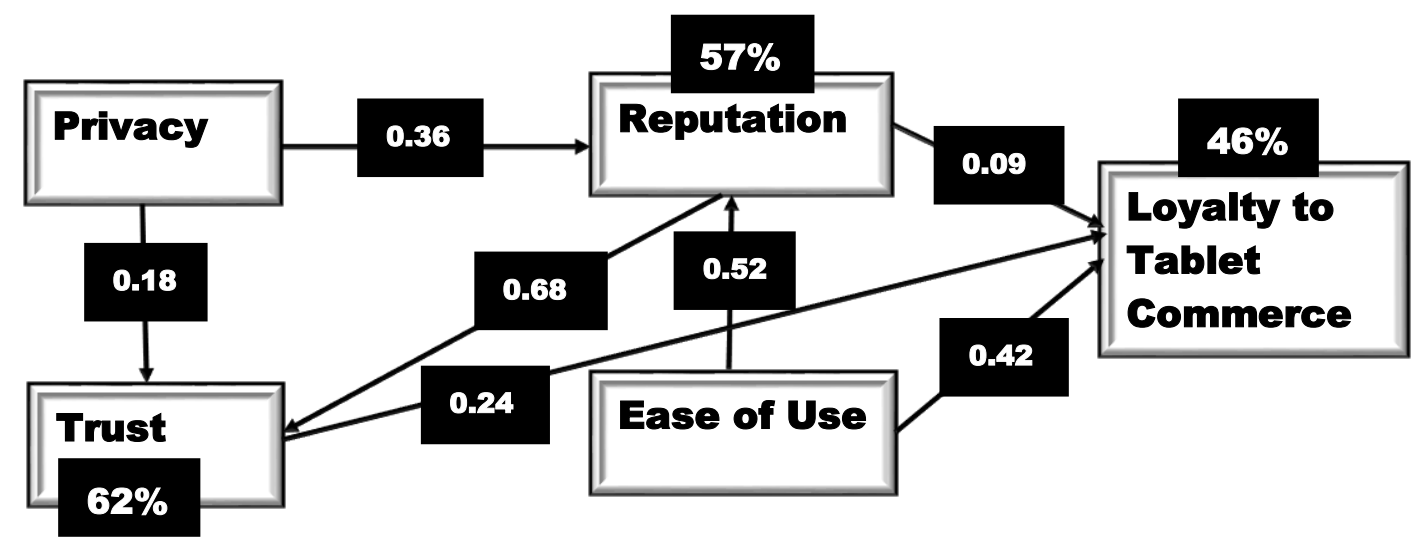

Fig. 2. Conceptual framework and Tested hypotheses

Table 4. Latent Variable Correlations

\begin{tabular}{lccccc}
\hline Construct & Ease of Use & Loyalty & Privacy & Reputation & Trust \\
\hline Ease of Use & $\mathbf{0 . 8 2 0}$ & & & & \\
Loyalty & 0.6394 & $\mathbf{0 . 7 8}$ & & & \\
Privacy & 0.4619 & 0.4757 & $\mathbf{0 . 7 4}$ & & \\
Reputation & 0.6795 & 0.5552 & 0.5943 & $\mathbf{0 . 8 2}$ & \\
Trust & 0.6838 & 0.5913 & 0.5746 & 0.7761 & $\mathbf{0 . 8 5}$ \\
\hline
\end{tabular}

*The square root of AVEs (shown in bold at diagonal) and factor correlation coefficients 
Table 5: Standardized path coefficients for Tablet Commerce General Model

\begin{tabular}{llccccc}
\hline Hypothesis & Path & $\begin{array}{c}\text { Sample } \\
\text { Mean (M) }\end{array}$ & $\begin{array}{c}\text { Standard } \\
\text { Deviation }\end{array}$ & T-Test & P-Value & $\begin{array}{c}\text { Hypothesis } \\
\text { Confirmed }\end{array}$ \\
\hline H1 & Privacy -> Trust & 0.1758 & 0.0491 & 3.5705 & .0412 & Yes \\
\hline H2 & Privacy -> Reputation & 0.3571 & 0.0548 & 6.5068 & .0001 & Yes \\
\hline H3 & Reputation -> Loyalty & 0.0897 & 0.0728 & 1.1823 & .7987 & No \\
\hline H4 & Reputation -> Trust & 0.672 & 0.0428 & 15.6948 & .0001 & Yes \\
\hline H5 & Trust -> Loyalty & 0.2394 & 0.0682 & 3.5042 & .0525 & Yes \\
\hline H6 & Ease of Use -> Reputation & 0.5153 & 0.0532 & 9.6868 & .0001 & Yes \\
\hline H7 & Ease of Use -> Loyalty & 0.4152 & 0.076 & 5.4944 & .0001 & Yes \\
\hline
\end{tabular}

* Two-tailed hypothesis. Significant at $p<.01$

\subsection{General Structural Model}

Table 5 shows the path coefficients and variation of the paths for the general structural model. The privacy assurance of using a tablet commerce platform will build a trusted customer's patronage, that is, Privacy $\rightarrow$ Trust $\beta=.18$ and $\mathrm{t}=3.57$, the result is significant at $(\mathrm{p}<0.01)$ and the privacy confidence of using a tablet commerce platform will affect its vendor reputation, that is, Privacy $>$ Reputation $\beta=.36$ and $t=6.51$, the result is significant at $(\mathrm{p}<0.01)$. The reputation of tablet commerce vendor will positively attract the customer's loyalty, Reputation -> Loyalty $\beta=.09$ and $\mathrm{t}=1.18$, the result is significant at $(\mathrm{p}<0.01)$ and the continuous reputation of tablet commerce vendor will positively heighten the trust of online retailing customers, Reputation $->$ Trust $\beta=.67$ and $\mathrm{t}=15.69$, the result is significant at $(\mathrm{p}<0.01)$. A trusted tablet commerce platform will attract customer's loyalty, that is, Trust $\rightarrow$ Loyalty $\beta=.24$ and $\mathrm{t}=3.50$, the result is significant at $(\mathrm{p}<$ 0.01 ). The convenience of using tablet commerce platform will boost the reputation of online vendor, Ease of use $->$ Reputation $\beta=.52$ and $\mathrm{t}=9.62$, the result is significant at $(\mathrm{p}<0.01)$ and the simplicity of tablet commerce platform will positively affect customer's loyalty, Ease of use -> Loyalty $\beta=.45$ and $t=5.49$, the result is significant at $(\mathrm{p}<0.01)$. In the overall model, reputation is the highest predictor of tablet commerce trust. All the hypotheses are supported except hypothesis 3 . The variance for the study explained $62 \%$ for tablet commerce trust, $57 \%$ for reputation and $46 \%$ for loyalty. According to the proposition of Leppäniemi, Jayawardhena, Karjaluoto, and Harness, (2017), the $\mathrm{R}^{2}$ for trust and reputation are above moderate while loyalty is near moderate. 


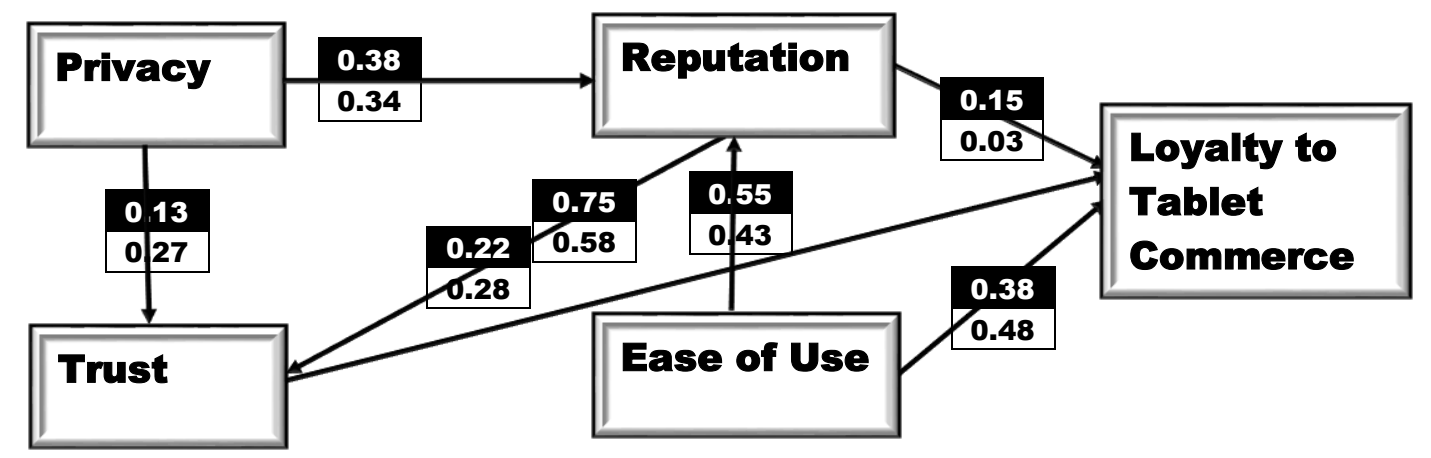

Male

Fig. 3. Multigroup Analysis (Male vs Female)

Female

Table 6: Gender Multigroup path coefficients and corresponding hypothesis results

\begin{tabular}{lcrll}
\hline & \multicolumn{1}{c}{ T-Test } & & & \\
\hline Path Coefficient & Male & Female & Different & Remark \\
\hline Ease of Use -> Loyalty & 3.07 & 5.72 & Yes & $\mathrm{A}$ \\
Ease of Use -> Reputation & 8.15 & 5.40 & Yes & $\mathrm{A}$ \\
Privacy -> Reputation & 5.14 & 4.01 & Yes & $\mathrm{A}$ \\
Privacy -> Trust & 2.04 & 3.41 & Yes & $\mathrm{A}$ \\
Reputation -> Loyalty & 1.35 & 0.28 & Yes & $\mathrm{NS}$ \\
Reputation -> Trust & 14.88 & 8.37 & Yes & $\mathrm{A}$ \\
Trust -> Loyalty & 2.18 & 2.85 & Yes & $\mathrm{A}$ \\
\hline * Two-tailed hypothesis. Significant at $\boldsymbol{p < . 0 1 . ~}$ A: Accepted; R: Rejected; NS: Not Significant &
\end{tabular}

\subsection{Tablet Commerce Gender Multigroup Model Assessment}

To confirm the gender differences of tablet commerce in emerging market context, the study embarked on multigroup analysis with SmartPLS Bootstrapping. The result reveals differences in perception of male and female based on the following path coefficient. The perception of ease of use and loyalty regarding tablet commerce is higher among female than male $(0.48 / 0.38)$ while the tablet commerce respondent's perception of ease of use and reputation is higher among male than female $(0.55 / 0.43)$. The perception of privacy and reputation is higher among male than female $(0.38 / 0.34)$ while privacy and trust perception is higher among female than male $(0.27 / 0.13)$. The association of reputation and loyalty is higher among male than female $(0.15 / 0.03)$. The reputation and trust perception of tablet commerce are higher among male than female $(0.75 / 0.58)$ while trust as a predictor of loyalty is higher among female than male $(0.28 / 0.22)$. All the paths are significant across the gender except reputation-loyalty (Table 6). The reputation of the online vendor is not a direct predictor of loyalty to tablet commerce.

\section{Discussion and Implication}

The extension of mobile commerce to tablet commerce is a turning point of customer's engagement in online shopping but despite the shift in commerce, the online vendors are yet to have full understanding of tablet commerce behavior and the online shoppers that owns the tablet 
device without using it for online shopping. In addition, the extant studies have not paid attention to gender variation of tablet use and their perception of the relationship of ease of use, privacy, trust, reputation, and loyalty. For instance, Hur, Kim, and Kim, (2014) used gender and age to moderate tablet computer adoption with perceived usefulness, perceived ease of use, perceived enjoyment and social influence as a direct predictor of attitude. To give explicit insight into these research problems, the study attempts to know the difference between tablet commerce loyalty of gender, in respect of trust and privacy concerns. The study also examines the ease of use as a determinant of tablet commerce success and as an extension of tablet commerce, vendor's continuous reputation and finally probe into how security issues such as privacy affect the tablet commerce gender. The study targets the tablet users and uses variance structural equation modelling to examine the relationship of the identified constructs. The study reveals that privacy, trust, reputation, and ease of use predicts tablet customer's loyalty positively with exception of reputation-loyalty and the perception of tablet commerce respondents differs.

The study reveals the online vendor's reputation as a big umbrella of brand reputation and service reputation as the study posit that the reputation of tablet commerce will intensify the tablet customer's trust in online shopping. The proposition was supported as reputation positively predicted trust as the highest predictor of tablet commerce model among male and female users. This is consistent with the study of Eisenegger, (2009) but contrast with Gommans, et. al. (2001). It indicates the reputable influence of online vendor to attract and influence the tablet customers with an outstanding brand engagement and a memorable service through a competent and efficient staff. The more the reputable online vendor is consistent with reputable branding and services, the higher the trust level of the tablet commerce customers. This study focusses on the tablet commerce vendor's reputation as a wider scope of innovative branding and topmost customer's services. Ease of use is the second highest predictor of online vendor's reputation in this study. The word of mouth spread like a wildfire whenever the tablet commerce platform such as designated website for tablet is easy to navigate. The third party always share their positive experience and this development successively publicize the online vendor as the enabler of the tablet commerce platform. This result is different from the study of Ribbink, et al. (2004) as ease of use significantly predicted customer's satisfaction with the online company services due to the user-friendliness of the company website. Also, the study finding is slightly similar to the work of Featherman, et al. 
(2010) as they suggested enhancement of ease of use and corporate credibility as an essential component of electronic services.

This study looks at the association of ease of use and reputation in place of credibility as reputation precedes credibility and the reputation of online vendor will lead to its credibility. Ease of use is the third predictor of tablet commerce loyalty and it reflects the importance of the simplicity of tablet commerce platform as an instrument of the positive influence of tablet commerce loyalty. Ease of use is a direct path of tablet commerce loyalty but contrary to the study of Ribbink, et al. (2004) where ease of use was used as an indirect predictor of electronic loyalty. It showcases simple tablet commerce platform as an efficient factor that can pull in tablet commerce loyalty without any intermediary. Privacy concern is a critical issue that is advancing in online shopping. It is restraining the online shopper to shop conveniently due to lack of confidence on tablet commerce vendor's reputation. There is a need for privacy assurance to promote the reputation of tablet commerce platform that will facilitate customer's repeated visit. Additionally, when there is a privacy confidence on a tablet platform, it will foster online shopping reputation and promptly advanced publicity of tablet commerce vendor. Privacy is a predictor of a reputation for tablet commerce and it signifies the higher the privacy assurance the higher the reputable perception of tablet commerce platform. Privacy for the second time also predicted trust. It means the privacy assurance will increase the trust level of tablet commerce customers. The finding aligns with the study of Roca, García, and Vega, (2009) but contrarily privacy was not a significant predictor of trust in online trading. This study differentiates itself as privacy predicts trust positively. Privacy and trust are essential in a tablet commerce success as they go together.

Loyalty has been studied extensively (Lin, et al. 2006) but its relevance is very paramount in tablet commerce. The study empirically validated the extant theories within the research domain of tablet commerce, and ascertain the explanatory power of privacy, trust, reputation, and ease of use on tablet commerce loyalty.

The study answers the research questions. First, the study reveals ease of use, reputation, privacy, and trust as the responsible factors for loyalty to tablet commerce in emerging markets of Africa. These factors have a direct and indirect relationship with loyalty for tablet commerce. Second, there are gender differences between the way the male and female users perceived tablet commerce constructs in this context. Third, the perception of ease of use, reputation, privacy, and trust as 
antecedents of tablet commerce loyalty by male and female tablet users differs. The Male tablet user's perceptions are stronger in ease of use-reputation, privacy-reputation and reputation-trust than female tablet users while the female perception dominates in ease of use-loyalty, privacytrust, and trust-loyalty. The intensity of female tablet user perception of ease of use of the tablet commerce optimized website and trust is higher for female than male tablet users.

The study extends the theory of loyalty with a new tablet commerce framework to have a proper understanding of tablet users on online commerce platform. The study found the factors that affect tablet users when shopping online in a developing country and contribute to tablet commerce literature. The study discovered a viable extended channel for online shopping in Nigeria and explains the central role of trust, the direct and indirect effect of reputation and ease of use as the final predictor of tablet commerce loyalty.

\subsection{Managerial Implication}

The result of this study firstly gives an insight to the tablet commerce practitioners that a reputable tablet commerce vendor requires a trusted brand; trusted tablet commerce workers and trusted tablet commerce platform functional will be helpful to attract repeated customers. There is no consensus existing from other disciplines such as sociology, economics, marketing, and management, either on a standard definition of brand trust, on its dimensionality, or approaches to its measurement as evident in the earlier definitions. Hobbs and Lassoued, (2015) see a brand as a quality cue on which consumers may rely to form expectations about the product's quality, including safety. According to Alam and Yasin, (2010), with investments in brand name capital, they have a stronger incentive to maintain product quality, to avoid damage to brand reputation and to boost consumer confidence in their products. The research premise is that consumer trust in brands, reputation, privacy, ease of use may evolve to confidence about the brands' attributes through experiencing the product and its benefits, which ultimately drives a consumer to be loyal to that brand. Secondly, the output of the study informs the tablet commerce stakeholders most especially the merchants and the vendors that privacy policy awareness and functional policy is profitable to build a trusted online environment that will impact customers with the assurance of shopping online with ease and this is a panacea for customer engagement. The assured privacy policy will also remove customers' tension and fear of unsecured online shopping platform. The mobile practitioners should work on this result to ensure that the tablet commerce-shopping 
platform is straightforward and easy to access without stress by making information accessible, navigation and check-out process easy. This innovation will prevent cart abandonment and nonproductive online shopping. Additionally, the online merchants should dichotomize tablet commerce strategy to be able to offer the best personalized products and services to male and female tablet users to increase productivity and higher sales revenue. Lastly, due to the accidental downtime of the mobile website, the tablet commerce should introduce tablet app to the tablet commerce customer for browsing, searching and online purchasing. This tablet app will complement a new channel of tablet device and it should have features for online shopping, shipping, product reviews, product returns, wishlists and daily deal. This tablet app should be versatile and optimize for tablet fast usability, zoom and pinch.

\subsection{Limitations and Future Research}

In this study, the authors focus on tablet commerce in Nigeria context and not Africa nor globally, but the proposed framework can be adopted in other countries due to rapid diffusion of tablet device. The study employed quantitative method with structural equation modelling but the future researchers should look into the connectedness of a secured online shopping platform with security, trust, and ease of use using a mixed methodology (Ozturk et al. 2016, Pappas 2016, Fathian, Hoseinpoor and Minaei-Bidgoli 2016). This mixed-methodology will enrich the study and pave the way for theoretical parsimony. The future researchers should also conduct a discriminant analysis on different types of mobile devices with a focus on tablet and smartphone. This result will give an insight into the discriminant level of the mobile devices in the context of mobile commerce. This extended study will help the mobile commerce practitioners to understand their customer's profile and help them to segment the mobile device users preferentially. The future researchers will find this research extension interesting.

\section{References}

Ackerman, M., Cranor, F. and Reagle, J. 1999. "Privacy in e-commerce: examining user scenarios and privacy preferences." In Proceedings of the first ACM conference on Electronic commerce, Denver, Colorado: 1-8.

Agag, G. M. and El-Masry, A. A. 2016. "Cultural and religiosity drivers and satisfaction outcomes of consumer perceived deception in online shopping." Internet Research, Vol. 26 (4): 942962. https://doi.org/10.1108/IntR-06-2015-0168. 
Ajzen, I. 1991. "The theory of planned behavior." Organizational Behavior and Human Decision Processes, 50 (2): 179-211.

Akbar, R., Pilcher, R. and Perrin, B. 2012. "Performance measurement in Indonesia: the case of local government." Pacific Accounting Review, 24 (3): 262-291.

Alam, S.S., Yasin, N.M. 2010. “Antecedents of online brand trust: Malaysian evidence." Journal of Business Economic Management 11 (2): 210-226.

Anderson, R.E. and Srinivasan, S.S. 2003. "E-satisfaction and e-loyalty: a contingency framework." Psychology \& Marketing, 20 (2): 123-138.

Ba, S., and Pavlou, P. A. 2002. "Evidence of the effect of trust building technology in electronic markets: Price premiums and buyer behavior." MIS quarterly, 26 (3): 243-268.

Bagozzi, R. P., and Yi, Y. 1988. "On the evaluation of structural equation models." Journal of the Academy of Marketing Science, 16 (1): 74-94.

Bekele, D. (2000). ElhioGift: A unique experience in electronic commerce in Ethiopia. Electronic Markets, 10, 146.

Beldad, A., M. de Jong, and M. Steehouder. 2010. "How Shall I Trust the Faceless and the Intangible? A Literature Review on the Antecedents of Online Trust." Computers in Human Behavior, 26 (5): 857-68.

Bredican, J. 2016. "Tablet computing and apps: A methodology for improved business productivity." South African Journal of Information Management. SSN 2078-1865, E-ISSN 1560-683X

Buttle, F. \& Maklan, S. (2015). Customer relationship management: concepts and tools (3rd ed.). New York: Routledge.

Carlos Roca, J., José García, J. and José de la Vega, J. 2009. "The importance of perceived trust, security and privacy in online trading systems." Information Management \& Computer Security, 17 (2): 96-113.

Casalo, L. V., C. Flavian, and M. Guinaliu. 2007. "The Influence of Satisfaction, Perceived Reputation and Trust on a Consumer's Commitment to a Website." Journal of Marketing Communications, 13 (1): 1-17.

Chang, L., et al. 2005. "A privacy trust behavioral intention model of electronic commerce." Journal of Information and Management, 42 (2): 289-30

Chan-Olmsted, S., \& Shay, R. 2016. "Understanding Tablet Consumers: Exploring the Factors That Affect Tablet and Dual Mobile Device Ownership." Journalism \& Mass Communication Quarterly, 93 (4): 857-883.

Chen, C. 2006. "Identifying Significant Factors Influencing Consumer Trust in an Online Travel Site." Information Technology and Tourism, 8:197-214.

Chen, S., \& Ning, J. 2002. "Constraints on E-commerce in less developed countries: The case of China." Electronic Commerce Research, 2 (1-2): 31-42.

Chong, A.Y.-L., 2013. "Predicting m-commerce adoption determinants: a neural network approach.” Expert System Application, 40 (2): 523-530.

Church, K., Smyth, B., Cotter, P. and Bradley, K. 2007. "Mobile information access: a study of emerging search behavior on the mobile internet." ACM Transactions on the Web, 1 (1): 138.

Coltman, T., Devinney, T. M., Midgley, D. F., \& Venaik, S. 2008. "Formative versus reflective measurement models: Two applications of formative measurement." Journal of Business Research, 61 (12): 1250-1262. 
Corbitt, B.J., Thanasankit, T., Yi, H. 2003. "Trust and e-commerce: a study of consumer perceptions". Electronic Commerce Research Application, 2 (3), 203-215.

Corritore, C. L., Kracher, B., and Wiedenbeck, S. 2003. "On-Line Trust: Concepts, Evolving Themes, a Model.” International Journal of Human-Computer Studies, (58:6): 737-758.

Curry, K., \& Cherner, T. 2016. "Social Studies in the Modern Era: A Case Study of Effective Teachers' Use of Literacy and Technology." The Social Studies, 107(4), 123-136.

Davis, F. D. 1989. "Perceived Usefulness, Perceived Ease of Use and User Acceptance of Information Technology". MIS Quarterly, 13 (3): 319-40.

Eisenegger, M. (2009). "Trust and reputation in the age of globalisation." In Reputation capital, 11-22, Springer Berlin Heidelberg.

Faqih, K. M., \& Jaradat, M. I. R. M. 2015. "Assessing the moderating effect of gender differences and individualism-collectivism at individual-level on the adoption of mobile commerce technology: TAM3 perspective." Journal of Retailing and Consumer Services, 22: 37-52.

Fathian, M., Hoseinpoor, Y., \& Minaei-Bidgoli, B. 2016. "Offering a hybrid approach of data mining to predict the customer churn based on bagging and boosting methods." Kybernetes, 45 (5): 732-743.

Featherman, M. S., Miyazaki, A. D., \& Sprott, D. E. 2010. "Reducing online privacy risk to facilitate e-service adoption: the influence of perceived ease of use and corporate credibility." Journal of Services Marketing, 24(3), 219-229.

Flavian, C., Guinaliu, M., and Gurrea, R. 2006. "The Role Played by Perceived Usability, Satisfaction and Consumer Trust on Website Loyalty." Information \& Management, (43), pp. 1-14.

Fornell, C.D. and Larcker F. 1981. "Evaluating structural equation models with unobservable variables and measurement errors." Journal of Marketing Research, 18 (1): 39-50.

Garcia-Mnrillo, M. 2004. "Institutions and the adoption of electronic commerce in Mexico." Electronic Commerce Research, 4: 201-219.

Gefen, D. 2002. "Customer Loyalty in E-Commerce," Journal of the Association for Information Systems, 3 (1): 2.

Gefen, D., E. Karahanna, and D. W. Straub. 2003. "Trust and TAM in Online Shopping: An Integrated Model." MIS Quarterly, 27 (1): 51-90.

Gefen, D., 2000. "E-commerce: the role of familiarity and trust." Omega 28 (6): 725-737.

Ghose, A., A. Goldfarb, and S. P. Han: 2012, 'How is the mobile Internet different? Search costs and local activities'. Information Systems Research, 24(3), 613-631.

Ghose, A., S. Han, and K. Xu: 2013, 'Mobile commerce in the new tablet economy'. In:

Proceedings of the 34th International Conference on Information Systems (ICIS), 1-18.

Gilbert, J. "Privacy? Who needs Privacy?" Business 2.0, 6 (2): 42-42.

Gommans, M., Krishman, K. S., and Scheffold, K. B. 2001. "From brand loyalty to e-loyalty: A conceptual framework.” Journal of Economic \& Social Research, 3 (1): 43-58.

Gregori, N., Daniele, R. and Altinay, L. 2014. "Affiliate Marketing in Tourism: Determinants of Consumer Trust." Journal of Travel Research, 53 (2): 196-210.

Gruen, T. W., Summers, J. O., and Acito, F. 2000. "Relationship marketing activities commitment, and membership behaviors in professional associations." Journal of Marketing, 64(3): 3449.

Ha, S. and Stoel, L., 2008. "Promoting customer-retailer relationship building: Influence of customer trustworthiness of customer loyalty programme marketing. " Journal of customer behavior, 7 (3): 215-229. 
Han, S. P., Ghose, A. and Xu, K. "Mobile commerce in the new tablet economy." In Proceedings of the 34th International Conference on Information Systems (ICIS), 1-18.

Han, T. H., B. Nguyenb, and T. J. Lee. 2015. "Consumer-based Chain Restaurant Brand Equity, Brand Reputation, and Brand Trust." International Journal of Hospitality Management 50: 84-93.

Haubl, G., and Trifts, V. 2000. "Consumer decision making in online shopping environments: the effects of interactive decision aids." Marketing Science, 19: 4-21.

Hawkins, K, and Vel., P. 2013. "Attitudinal loyalty, behavioural loyalty and social media: An introspection." The Marketing Review 13 (2): 125-141.

Helm, S. 2006. Exploring the impact of corporate reputation on consumer satisfaction and loyalty. Journal of Customer Behaviour, 5 (1): 59-80

Herbig, P., J. Milewicz, and J. Golden. 1994. "A Model of Reputation Building and Destruction." Journal of Business Research 31:23-31.

Hinde, S. 1998. "Privacy and security - The drivers for growth of E-commerce." Computers and Security, 17: 475-478.

Hobbs, J. E and Lassoued, R. 2015. "Consumer confidence in credence attributes: The role of brand trust." Food Policy, 52: 99-107.

Hsu, M. H., C. M. Chang, K. K. Chu, and Y. J. Lee. 2014. "Determinants of Repurchase Intention in Online Group- Buying: The Perspectives of DeLone \& McLean IS Success Model and Trust." Computers in Human Behavior, 36:234-45.

Hur, W. M., Kim, H. and Kim, W. M. 2014. "The moderating roles of gender and age in tablet computer adoption." Cyberpsychology, Behavior, and Social Networking, 17 (1): 33-39.

Jantan, M., Ramayah, T., and Chin, W. W. 2001. "Personal Computer acceptance by small and Medium sized companies evidence from Malaysia." Journal of Management \& Business, 3(1): 1-14.

Josang, A., Ismail, R. and Boyd, C. 2007. "A Survey of Trust and Reputation Systems for Online Service Provision.” Decision Support Systems, 43:618-44.

Kamel, S., and Hussein, M. 2004. "King Hotel goes online: The case of a medium enterprise in using E-commcrec." Journal of Electronic Commerce in Organizations, 2:101-115.

Keller, K.L. 1993. “Conceptualizing, measuring, and managing customer- based equity.” Journal of Marketing, 57 (1): 1- 22.

Khuhro, R., Qureshi, Q., Humayon, A., Tahir, S. and Khan, A. 2016. "Factors affecting adoption behavior for Tablet device among computer users in Pakistan." Management Science Letters, 6(12): 723-734.

Kim, H. W., Y. Xu, and J. Koh. 2004. "A Comparison of Online Trust Building Factors between Potential Customers and Repeat Customers." Journal of the Association for Information Systems, 5 (10): 392-420.

Kim, K., Lim, J. H., Proctor, R. W. and Salvendy, G. 2016. "User Satisfaction with Tablet PC Features." Human Factors and Ergonomics in Manufacturing \& Service Industries, 26 (2): 149-158.

Kim, S.H. and Byramjee, F. 2014. "Effects of risks on online consumers' purchasing behavior: are they risk-averse or risk taking?" Journal of Applied Business Research, 30 (1): 161172.

Koufaris, M., and W. Hampton-Sosa. 2004. "The Development of Initial Trust in an Online Company by New Customers.” Information \& Management, 41:377-97. 
Kuo, L. 2013. "How the "Alibaba of India" is teaching India to trust online shopping." Available at: http://qz.com/147127/how-the-alibaba-of-india-is-teaching-india-totrustonline- shopping/2013 (Accessed on 30.03.2018).

Leppäniemi, M., Jayawardhena, C., Karjaluoto, H., and Harness, D. 2017. "Unlocking behaviors of long-term service consumers: the role of action inertia." Journal of Service Theory and Practice, 27 (1): 270-291.

Li, D., Browne, G. J., and Wetherbe, J. C. 2006. "Why Do Internet Users Stick with a Specific Web Site? A Relationship Perspective.” International Journal of Electronic Commerce 10 (4): 105-141.

Li, Y. (2014). The impact of disposition to privacy, website reputation and website familiarity on information privacy concerns. Decision Support Systems, 57: 343-354.

Lim, K., Sia, C. L., Lee, M. K. O., and Benbasat, I. 2006. "How Do I Trust You Online, and If So, Will I Buy? An Empirical Study on Designing Web Contents to Develop Online Trust," Journal of Management Information Systems, 23 (2): 233-266.

Lin, H. H., \& Wang, Y. S. 2006. "An examination of the determinants of customer loyalty in mobile commerce contexts." Information \& management, 43 (3): 271-282.

Liu, Y., Chen, Y. and Zhou, C. 2010. "Determinants of Customer Purchase Intention in Electronic Service." In proceedings of 2nd International Conference on E-business and Information System Security, 1-4.

Lowry, P. B., \& Gaskin, J. 2014. "Partial least squares (PLS) structural equation modeling (SEM) for building and testing behavioral causal theory: When to choose it and how to use it." IEEE Transactions on Professional Communication, 57 (2): 123-146.

Luhmann, N. (1979). Trust and Power, London: John Wiley \& Sons.

Mayer, R. C., Davis, J. H., \& Schoorman, F. D. 1995. "An integrative model of organizational trust. Academy of management review." 20 (3): 709-734.

McKnight, D., Cummings, L. L. and Chervany, N. 1998. "Initial Trust Formation in New Organizational Relationships." Academy of Management Review 23 (3): 473-490.

Metzger, M. J. 2004. "Privacy, trust, and disclosure: Exploring barriers to electronic commerce." Journal of Computer-Mediated Communication, 9(4), 00-00.

Molla. A., \& Licker, P. S. 2005. "Perceived e-readiness factors in e-commerce adoption: An empirical investigation in a developing country." International Journal of Electronic Commerce, 10: 83-110.

Mulpuru, S. and Epps, S. R. 2011. "Why tablet commerce may soon trump mobile commerce. http://www.officeproductnews.net/sites/default/files/XeroxMobileTechnology.p df.

Ndubisi, N. O., Jantan, M., \& Richardson, S. 2001. "Is the technology acceptance model valid for entrepreneurs? Model testing and examining usage determinants." Asian Academy of Management Journal, 6(2): 31-54.

Nilashi, M., Ibrahim, O., Mirabi, V. R., Ebrahimi L \& Zare, M. 2015. "The role of Security, Design and Content factors on customer trust in mobile commerce." Journal of Retailing and Consumer Services 26: 57-69

Odom, M., Kumar, A., \& Saunders, L. 2002. "Web assurance seals: How and why they influence consumers' decisions." Journal of Information Systems, 16 (2): 231-250.

Olaleye, S. A. 2016. "Customer Vs. E-tailer: How Tablet Affects Mobile Commerce." Journal of Emerging Trends in Marketing and Management, 1 (1): 224-235. 
Olaleye, S. A., Oyelere, S.S., Sanusi I.T. and Joseph, A. F. 2018. "Experience of Ubiquitous Computing Technology Driven Mobile Commerce in Africa: Impact of Usability, Privacy, Trust, and Reputation Concern." International Journal of Interactive Mobile Technologies (iJIM), 12(3).

Olaleye, S. A., Salo, J., and Ukpabi, D. C. 2018. "The Role of Reputation on Trust and Loyalty: A Cross-Cultural Analysis of Tablet E-Tailing." International Journal of E-Business Research (IJEBR), 14 (2): 61-75.

Olatokun, W. M. 2009. "Analysing socio-demographic differences in access and use of ICTs in Nigeria using the capability approach." Issues in Informing Science \& Information Technology, 6.

Ozturk, A. B., Bilgihan, A., Nusair, K. and Okumus, F. 2016. "What keeps the mobile hotel booking users loyal? Investigating the roles of self-efficacy, compatibility, perceived ease of use, and perceived convenience." International Journal of Information Management, 36 (6): 1350-1359.

Pappas, N. 2016. "Marketing strategies, perceived risks, and consumer trust in online buying behaviour." Journal of Retailing and Consumer Services, 29: 92-103.

Pavlou, P.A., 2003. "Consumer acceptance of electronic commerce: integrating trust and risk with the technology acceptance model." International Journal of Electronic Commerce 7(3): 101-134.

Pew Research 2013. "Tablet Ownership 2013" http://www.pewinternet.org/2013/06/10/tablet-ownership-2013/, accessed 30.03.2018.

Pew Research Center, 2018. "Mobile Fact Sheet". Available at: http://www.pewinternet.org/factsheet/mobile/, accessed 30.03.2018.

Piao, C., Li, C., Pan, X. and Zhang C. 2016. "User privacy protection for a mobile commerce alliance." Electronic Commerce Research and Applications, 18: 58-70

Qureshi, I., Fang, Y., Ramesy, E., McCole, P., Ibboston, P., and Compeau, D. 2009. "Understanding Online Customer Repurchasing Intention and the Mediating Role of Trust: An Empirical Investigation in Two Developed Countries," European Journal of Information Systems, 18(3): 205-222.

Ramayah, T. 2005. "Course Website Usage among Distance Learning Business Students: The Role of Prior Experience." International Journal of Learning, 11: 1507-1517

Ramayah, T. 2006. "Course Website Usage: Does Prior Experience Matter.” WSEAS Transactions on Information Science \& Applications, 2 (2): 299-306.

Ramayah, T. 2010. "The Role of Voluntariness in Distance Education Students' Usage of a Course Website." Turkish Online Journal of Educational Technology, 9 (3): 96-105.

Ramayah, T., and Ignatius, J. 2005. "Impact of perceived usefulness, perceived ease of use and perceived enjoyment on intention to shop online." ICFAI Journal of Systems Management (IJSM), 3 (3): $36-51$.

Ramayah, T., and Lee, S. L. 2005. "Kesan Persepsi Kebergunaan, Kesenangan Mengguna dan Keseronokan Mengguna Terhadap Penggunaan E-mel. Jurnal Kemanusiaan." 5: 23-36.

Ramayah, T., \& May-Chiun, L. 2007. "Impact of shared beliefs on "perceived usefulness"' and "ease of use", in the implementation of an enterprise resource planning system." Management Research News, 30 (6): 420-431.

Ramayah, T., Ignatius, J. and Aafaqi, B. 2005. "PC Usage among Students in a Private Institution of Higher Learning: The Moderating Role of Prior Experience." Educators and Education Journal, 20: 131-152. 
Ramayah, T., Jantan, M. and Aafaqi, B. 2003. "Internet Usage among Students of Institutions of Higher Learning: The Role of Motivational Variables." The Proceedings of the 1st International Conference on Asian Academy of Applied Business Conference, Sabah, Malaysia, 10-12th July, 2003.

Ramayah, T., Ma'ruf, J. J., Jantan, M., and Osman, M. 2002. 'Technology Acceptance Model: is it applicable to users and non-users of internet banking." The proceedings of The International Seminar, Indonesia- Malaysia, The role of Harmonization of Economics and Business Discipline in Global Competitiveness, Banda Aceh, Indonesia, 2002.

Ribbink, D., Van Riel, A. C., Liljander, V. and Streukens, S. 2004. "Comfort your online customer: quality, trust and loyalty on the internet." Managing Service Quality: An International Journal, 14(6), 446-456.

Ringle, C. M., Sarstedt, M. and Straub, D. 2012. "A critical look at the use of PLS-SEM. MIS Quarterly, 3-16.

Robinson, R., and Smith, C. 2002. "Psychosocial and demographic variables associated with consumer intention to purchase sustainably produced foods as defined by the midwest food alliance." Journal of Nutrition Education and Behavior, 34 (6): 316-325.

Rodgers, S., and Harris, M. A. 2003. "Gender and e-commerce: An exploratory study." Journal of advertising research, 43(3): 322-329.

Romero, D., \& Molina, A. 2011. "Collaborative networked organisations and customer communities: value co-creation and co-innovation in the networking era." Production Planning \& Control, 22 (5-6): 447-472.

Sarstedt, M., Ringle, C. M., Henseler, J. and Hair, J. F. 2014. "On the emancipation of PLS-SEM: A commentary on Rigdon (2012)." Long range planning, 47 (3): 154-160.

Selim, H. M. 2003. "An empirical investigation of student acceptance of course websites." Computers \& Education, 40: 343-360.

Selnes, F. 1993. "An examination of the effect of product performance on brand reputation, satisfaction and loyalty." European Journal of marketing, 27 (9): 19-35.

Sha, W., 2009. "Types of structural assurance and the irrelationships with trusting intentions in business-to-consumer e-commerce." Electronic Marketing 19: 43-54.

Shah, M.H., Okeke R. and Ahmes R. 2013. "Issues of Privacy and Trust in E-Commerce: Exploring Customers' Perspective." Journal of Basic and Applied Scientific Research, 3(3): 571-577.

Smeltzer, L. 1997. "The Meaning and Origin of Trust in Buyer- Seller Relationships." International Journal of Purchasing and Materials Management, 33 (1): 40-48.

Smith, R., 1998. "Can you bribe your way to customer loyalty?" Frequency marketing strategies. Strategic Research Institute, New York.

Sohn, T., Li, K.A., Griswold, W. and Hollan, J. 2008. "A diary study of mobile information needs". Proceedings of the SIGCHI Conference on Human Factors in Computing Systems, ACM, Florence.

Song, Y., Ma, H., Wang, H., and Wang, K. 2013. "Exploring and exploiting user search behavior on mobile and tablet devices to improve search relevance." In Proceedings of the 22nd international conference on World Wide Web, 1201-1212, ACM.

Strauss, B. \& Seidel, W. (2004). Complaint management: The heart of CRM. Mason, Ohio: Thomson.

Tavakol, M. and Dennick R. 2011. "Making sense of Cronbach's alpha.” International Journal of Medical Education. 2: 53-55. 
Teo, T. S., and Liu, J. 2007. "Consumer Trust in E-commerce in the United States, Singapore and China." Omega 35:22-38.

Thakur, R. 2016. "Understanding Customer Engagement and Loyalty: A Case of Mobile Devices for Shopping." Journal of Retailing and Consumer Services, 32: 151-163

Toms, E. G., and Taves, A. R. 2004. "Measuring User Perceptions of Website Reputation." Information Processing and Management, 40:291-317.

Tung, F. C., Chang, S. C. and Chou, C. M. 2008. "An Extension of Trust and TAM Model with IDT in the Adoption of the Electronic Logistics Information System in HIS in the Medical Industry." International Journal of Medical Informatics, 77:324-35.

Vargo, S. L. and Lusch, R. F. (2004). Evolving to a New Dominant Logic for Marketing. Journal of Marketing, 68(January), 1-17.

Venkatesh, V., \& Davis, F. D. 2000. "A theoretical expansion of the technology acceptance model: Four Longitudinal field studies.” Management Science, 46 (2): 186-204.

Vermeulen, I. E., and D. Seegers. 2009. "Tried and Tested: The Impact of Online Hotel Reviews on Consumer Consideration." Tourism Management, 30 (1): 123-27.

Wang, Q., Cui, X., Huang, L and Dai, Y. 2016. "Seller reputation or product presentation? An empirical investigation from cue utilization perspective." International Journal of Information Management, 36: 271-283.

Weiser, E. B. 2000. "Gender differences in Internet use patterns and Internet application preferences: A two-sample comparison." CyberPsychology and Behavior, 3 (2): 167-178.

Westin, A. 1967. "The right to privacy.” New York: Athenaeum.

Widing, R., Sheth, J. N., Pulendran, S., Mittal, B., \& Newman, B. J. (2003). Customer Behaviour: Consumer behaviour and beyond. South Melbourne, Victoria: Thomson.

Wong, K. K. K. 2013. "Partial least squares structural equation modeling (PLS-SEM) techniques using SmartPLS." Marketing Bulletin, 24 (1): 1-32.

Wua, K-W, Huang, S. Y., Yen D. C. and Popova. I. 2012. "The effect of online privacy policy on consumer privacy concern and trust." Computers in Human Behavior, 28: 889-897

Xu, K., Chan, J., Ghose, A., \& Han, S. P. 2016. "Battle of the channels: The impact of tablets on digital commerce." Management Science, 63(5), 1469-1492.

Yoon, H. S \& Occena, L. G. 2015. "Influencing factors of trust in consumer-to-consumer electronic commerce with gender and age." International Journal of Information Management, 35: 352-363.

\section{APPENDIX}

Electronic and Mobile Commerce Merchants in Nigeria

\begin{tabular}{llll}
\hline No. & Name & Type of Merchant & Website \\
\hline 1. & Yudala & General Merchandise Retailer & $\underline{\text { http://www.yudala.com/ }}$ \\
2. & Slot & Specialty Retailer & $\underline{\text { http://slot.ng/ }}$ \\
3. & Taafoo & Specialty Retailer & http://www.taafoo.com/ \\
4. & Jumia & General Merchandise Retailer & http://www.jumia.com.ng/ \\
5. & Konga & General Merchandise Retailer & http://www.konga.com/ \\
6. & Ohmasshoes & Specialty Retailer & $\underline{\text { http://www.ohmashoes.com/ }}$ \\
\hline
\end{tabular}




\begin{tabular}{|c|c|c|c|}
\hline 7. & Shopkudi & Specialty Retailer & http://shopkudi.kancart.com/\#!1 \\
\hline 8. & Dealdey & General Merchandise Retailer & http://www.dealdey.com/ \\
\hline 9. & Fastforwardstores & Specialty Retailer & http://www.fastforwardstores.com/ \\
\hline 10. & Hotels & Retail Agency & http://www.hotels.ng/ \\
\hline 11. & Hellofood & Specialty Retailer & https://www.hellofood.com.ng/ \\
\hline 12. & Pcplanet & Specialty Retailer & http://www.pcplanet.com/ \\
\hline 13. & Mystore & General Merchandise Retailer & http://www.mystore.com.ng/ \\
\hline 14. & Shopaholicng & Specialty Retailer & http://shopaholicng.com/ \\
\hline 15. & Walahi & Specialty Retailer & http://walahi.com/ \\
\hline 16. & Buyright & Specialty Retailer & http://buyright.biz/ \\
\hline 17. & Gloo & Specialty Retailer & http://gloo.ng/ \\
\hline 18. & Mannastores & Retail Agency & https://www.mannastores.com/ \\
\hline 19. & Adibba & Specialty Retailer & http://www.adibba.com/ \\
\hline 20. & Easyappetite & Specialty Retailer & http://www.easyappetite.com/ \\
\hline 21. & Laurensonline & Specialty Retailer & http://www.laurensonline.com \\
\hline 22. & Smartbuy & Specialty Retailer & http://www.smartbuy.ng/ \\
\hline 23. & Yakora & Specialty Retailer & http://www.yakora.ng/ \\
\hline 24. & Virgincodestore & Retail Agency & http://www.virgincodestore.com/ \\
\hline 25. & Teedaywholesale & Specialty Retailer & http://teedaywholesale.com/ \\
\hline 26. & Kara & Specialty Retailer & http://www.kara.com.ng/ \\
\hline 27. & Fashpa & Specialty Retailer & http://www.fashpa.com/ \\
\hline 28. & Mallforafrica & Retail Agency & http://www.mallforafrica.com/ \\
\hline 29. & Jiji & Retail Agency & http://jiji.ng/ \\
\hline 30. & Property24 & Retail Agency & http://www.property24.com.ng/ \\
\hline 31. & Furnish & Retail Agency & https://www.furnish.ng/ \\
\hline 32. & Showroom & Retail Agency & http://showroom.ng/ \\
\hline 33. & Cheki & Retail Agency & https://www.cheki.com.ng/ \\
\hline 34. & Wakanow & Retail Agency & http://www.wakanow.com/en-ng/ \\
\hline 35. & Coliseum & Specialty Retailer & http://www.coliseum.com.ng/ \\
\hline
\end{tabular}

